\title{
7. UNIVERSAL STUDIOS OF ART: PROFESSIONALIZATION AND CONTRIBUTIONS TO ART EDUCATION IN NIGERIA
}

Augustine Okola Bardi ${ }^{78}$

\begin{abstract}
During the $2^{\text {nd }}$ Black World and African Festival of Arts and Culture (FESTAC) in 1977, a lot of novel, creative and artistic events took place in Lagos. One of these was the construction of a monument, the National Arts Theatre, which also accommodated the National Gallery of Art. Invariably, the presence of the Gallery made the Arts Theatre management allocate the premises of the Theatre to some notable Nigerian artists for use as Artists in Residence. The premises eventually, by 1980, became an institutional and inspirational workshop for budding Nigerian artists. The activities of the artists were so professionally accepted that it was named the National Studios of Art. However, at the time the Studio had become the centre of sound informal art training, it was given a relocation order which caused serious controversy between the Gallery and the artists. The artists eventually accepted the relocation order, and this, necessarily, led to changing the name to the Universal Studios of Art (USA). As the professional artists became globally known, the USA also became a tourist centre for both local and foreign visitors and artists. Till today, the activities of the USA continue to attract national and international attention. Very as unfortunately, no scholarly study of the Universal Studios of Art has been carried out, despite its outstanding professional qualities.. For many years, the artists have developed valuable art forms and art styles that have contributed to the advancement of modern Nigerian art. It is the objective of this article, therefore, to document the artists of the Universal Studios of Art

Key words: Arts Theatre, Budding Nigerian artists, Universal Studios of Art, Valuable art works, Advancement of Nigerian art
\end{abstract}

\section{Introduction}

Art creativity remains an integral function of an artist in a school, workshop or studios. In the fifteenth and sixteenth centuries in Europe, an amateur artist working under the apprenticeship system for a master in workshops and schools became very popular (Abaje, 2008, p. 20) This popularity blossomed with young unemployed youths and art enthusiasts wanting to work and be inspired by the great masters in art who had practiced under great masters to learn a vocation (The Guardian, 2008, p. 118). Also during this period, workshop practices became very popular, mostly in Western Europe when draughtsmen were employed by various governments to teach art at the elementary stage. In 1585 , a generally accepted consensus came from a crucial meeting in Rome, Italy that assistance must be extended to the youth to build their talents around art. As a result of this agreement, workshops and studios started springing up, firstly in Cologne, Berlin, Munich and Dusseldorf in Germany, where Rembrandt had his educational apprenticeship programme. This programme awareness extended to other big cities and centres in Amsterdam and Rotterdam in Netherland where Vincent Van Gogh trained, From there, the awareness programme moved to Paris, Lyon, Bordeaux, Nancy, Aix en Province, Lille and many other centres in

\footnotetext{
${ }^{78}$ Associate Professor PhD., University of Benin, from Benin City, Nigeria, email: bardiaustin@ yahoo.com
} 
France, where prominent artists like Gauguin, Cézanne, Claude Monet, Edouard Manet as well as great impressionists like Renoir, Chagall, Rapael, Les Freres Nains (The Nain Brothers) and other great artists, underwent artistic training. (Gauvard, 1999, pp. 116-121). At this period, the high demand to practise art stimulated probably movements in Europe. These movements include Renaissance, Cubism, Impressionism and many others. (Idem, p. 122).

In Nigeria, for example, the idea of the Catholic mission headed by Reverend Father Patrick Kelly in the 1940s in Ekiti division of the old Ondo province where colonization and Christian evangelism had done much damage to the creative traditions of woodcarving, (Oloidi, O. 2011, pp. 14-16) was surprisingly restored by the Catholic diocese in its attitude to assist in the creative conceptualization in wood carving by the Yoruba in a school directed by Father Kevin Carroll at Oye Ekiti. (Idem, p. 17). Similarly, the Mbari-Mbayo experiments mobilized the youth who were trained free of charge in various artistic formation. The Ori-Olokun workshop also trained youth and matured artists within the Ibadan and Ile-Ife regions with art Educational fundamentals, which got a resounding success in textile design, graphic design, painting and bead making, to mention but a few. The Abayomi Barber School exposed the youth to modern Nigerian art tradition teaching from stage to stage drawing techniques thereby helping to enrich the art historical account of modern Nigerian art. There was the Oshogbo school whose creative potentials were not appreciated at inception until its success became indisputably accepted by all. The latter workshops have produced countless artists with modernistic approach to art. In all, knowledge dissemination that characterized these workshop centres is the same with that of the Universal Studios of Art: a centre of creativity, ideology and social commune under Bisi Fakeye, a leader with great talent. The Universal Studios of Art (USA) has become not only an education forum, but also a tourist centre.

\section{Professionalization and Contributions}

Hutyrova describes fine art expressions as a communicative instrument worldwide that had been in useful existence from time past. He further stresses that it has also played basic roles as it is used as therapeutic formula in treating behavourial attitudes. He also writes that art is an important tool in all spheres of humanity. He states further that fine art objects stimulates feelings and as such can be safe to normalize an unstable situation and as a result it must be sustained to serve its purpose (Hutyrova, 2016, pp. 284-285). The attribute of a professional artist is "in his ability to face challenges and acquire skills to better his trade". Training remains a factor, which is primarily needed in the art practice. The establishment of the Universal Studios of Art was to impact knowledge, discover talent and help youth to be self-employed (Plate 1). (Bankole, 2004, p. 15). The transformation of the youth in art will bring about creativity, originality and excellence in them (Wangboje, 1998, pp. 11-15). The transformation of the walls of the studio has created standard that is yet to be equaled by other workshops and studios within and outside Lagos. For example, 
"the studio has five vibrant sections, sculpture, painting, ceramics, graphics, and textiles. The instructors as they are called teach the participants the basic art forms and techniques". (An Interview). The participants are trained to become professionals by improving their drawing skills. The objective of the programme is to make each participant attain a good level of professionalism at the end of the programme (An Interview).

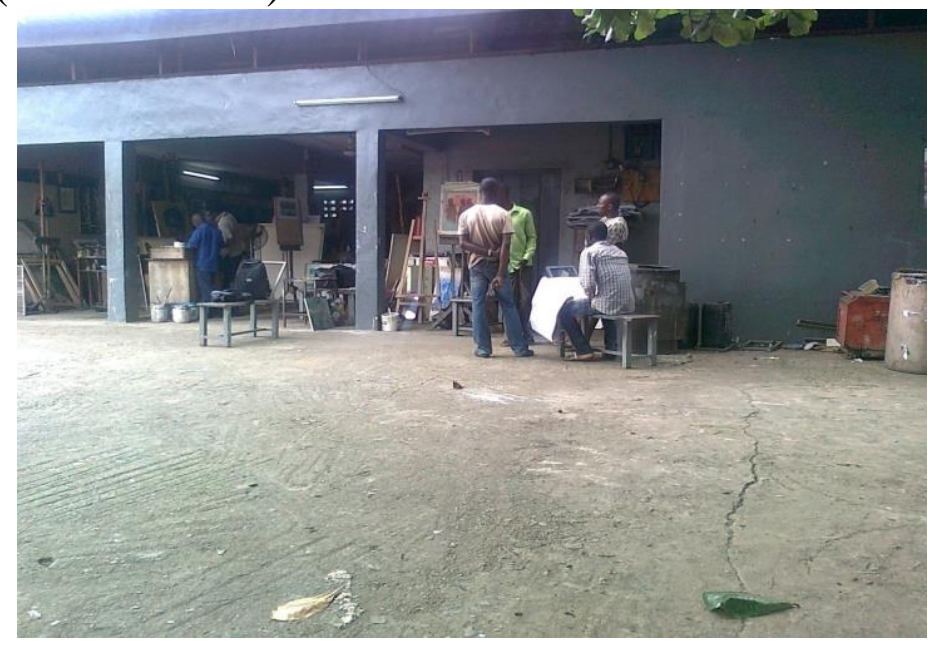

Plate 1: Self Employed Youths ( $)$ Augustine Bardi

The management of the studio organizes exhibition regularly. Artistic competitions are organized for participants to ascertain and verify their creative capabilities. The studio organized her inaugural exhibition in 1996 to test the practical knowledge of the members. (Exhibition Catalogue, 1996, pp. 1-2). The exhibition titled Stride in Time was staged from the $12^{\text {th }}-25^{\text {th }}$ April, 1996. As a collective initiative of young and the old vibrant artists, most of whom were members of the Society of Nigerian Arts (S.N.A) at that time, the studio presented for the exhibition renowned artists like Bisi Fakeye, Monday Akhidue, Shyngle A. Alex, Olubunmi Babatunde, Olaku A. O., Karunwi K. K., Buwa Temietan, Agose Patrick, Alli Olayinka, Olatunbi Lekan and Osatuma Iyomona, (Exhibition Catalogue, 2005, pp. 11-12).

Another exhibition that kept the studio alive was Resurgence which was on from April 8-18, 2006. It involved all participants of the Universal Studios of Art who were commemorating their ten years of professional practice. (Exhibition Catalogue, 2006, pp. 7-28). The studio also presented skillful artists such as Bisi Fakeye, Monday Akhidue, Abiodun Olaku, Bunmi Babatunde, Mufu Onifade and Fidelis Odogwu. Others were Patrick Agose, Francis Uduh, Wallace Ejoh, Joshua Nmesirionye and Osatuma Iyomona. Five members of the studios, Kazeem Karunwi, Temitan Buwa, Alli Olayinka and Lekan Olatunbi, were also participants at the inaugural exhibition in 1996. The studio has a policy of running exhibitions, conferences and seminars at every outing by members. Till date, the studio has, on record, three symposia in 1996, 2005 and 2007.The symposia had a reasonable attendance with Kehinde Ademuleya's documentating the art works of the artists.(The Guardian, 2008, p. 105). The authority of the Universal Studios of Art, seeing the maturity and the behavioural attitude of participants, further stimulated their desire for more 
activities by establishing periodic workshops to allow them discover their hidden potentials.

The Universal Studios of Art commands respect that is immeasurable, being a centre of artistic training and practice that has put its name on the world map through commissions and exhibitions and through participations in art residency at home and abroad. (The Guardian, 2007, p. 85). Some members of the studio have attended residency programmes. Some of them are Osatuma Iyomona, who attended artist-in-residence programme at Ecole Universite de Lome, Togo in 2008, as well as Patrick Agose, Francis Uduh and Monday Akhidue who attended residency programme in Greatmore Art studios, Woodstock, Cape Town, South Africa in 2009. In 2010, Mufu Onifade attended a three month residency programme with four International artists, eight local artists and twenty-five Thupelo artists from the localities of the Cape Coast in South Africa. (The Guardian, 2008, p. 107). Bunmi Babatunde was a guest lecturer at the Nanjing Normal University in China in the 2009, while Wallace Ejoh and Joshua Nmesirionye participated in the Harmattan Workshop Experiments at Agbarha-Otor in 2010. (An Exhibition Catalogue, 2007, p. 18).

Embassies and corporate bodies have been commissioning the artists from the studio since 1997. The Artists have been producing the calendar and almanac for the Central Bank of Nigeria (CBN), United Bank of Africa (UBA), Oceanic Bank, Eco-Bank Plc and First Bank Plc. Illustrations for book covers, files and C.D. jackets have also been produced by the artists of the studio. They are regularly commissioned to produce them, at a much cheaper rate compared to other established professionals. Patronage also comes from the Ministries of Aviation, Agriculture, Health, Education and even the Army, Police, Air-force and Navy, during their anniversary celebrations. The twentieth century has seen the emergence of new art forms in Africa, and in Nigeria in particular. These art forms were greatly influenced by many factors, which include colonial dominance, struggles for political independence and cultural emancipation. The late 1980s in Nigeria saw the advancement and development of modern Nigerian artists who started to evolve indigenous art themes and creative ingenuity (Oloidi, 1989, p. 96). These art themes were deeply rooted in, and have relationship to, Africa's traditional philosophy and myths. The Universal Studios of Art started under the leaders who had acquired creative experience for many years, after going through series of experimental freedom, artistic expression and stylistic methodology in the course of their art practice.

As fine art is an element of creative and of a communicative source, so movement has over centuries according to Vasiliu has acted as means of aesthetical enjoyment among the peoples of the world, She further, explains the undiluted folkloric music which is termed as a creative entity with a close relationship to creativity in art (Vasiliu, 2016, p. 115). The Universal Studios of Art has gathered a corpus of creative artists who have contributed immensely to the development of contemporary Nigerian art. Bisi Fakeye learnt both the modern and traditional art forms back in his home town of Ila-Orangun and he is now using the knowledge acquired to impact on the new generations of Nigerian 
artists. Bunmi Babatunde has a knack for ebony and cam wood, and he has transferred the likeness of this favourite medium of expression that he uses to the budding Nigerian artists. Monday Akhidue is highly regarded for his reflection on the techniques and styles of Benin traditional sculpture which he has passed over to his close kinsmen (The Daily Sun, 2009, p. 28). Francis Uduh and Patrick Agose's techniques of cold cast have been uniquely adopted by their pupils at the studio of art. Abiodun Olaku's symphony of colours has greatly influenced the colour symbolism that is powerfully reflected in the works of many Nigerian artists. Mufu Onifade has developed the technique and style of painting that he calls araism which has become part of modern Nigerian art. Wallace Ejoh's cool colour techniques have also served as a model to some artists with exceptional talent (Resurgence, Exhibition Catalogue, 2006, p. 13). Specifically, the contributions of the Universal Studios of Art to the development of art in Nigeria can be discussed under the following factors: portrayal of socio-political condition of Nigeria in art works, acquisition of conducive environmental for art practice, training of Nigerian youth and promotion of Nigeria's cultural heritage through tourism (The Vanguard, 2008, p. 38).

\section{Portrayal of Socio-Political condition of Nigerian in Artworks}

According to Poliakova, and Kralova, movement in humans carry aesthetical expression and are ways of artistic creativity. Both authors describe movement as compared to art realization, appreciation and evidently a tool to solving disorderliness. In other words art must be taught to have continuity (Poliakova \& Kralova, 2015, p. 264). The artists of the Universal Studios of Art have produced art works that depict socio-political unrest and condition of living in Nigeria. A good example is the issue of June 12, 1993 that Bisi Fakeye has revisited in his sculptural piece titled June 12. Bunmi Babatunde also produced a gigantic work titled June 12 in memory of Chief M.K.O. Abiola the acclaimed winner of the presidential election that was annulled in June 121993 by Ibrahim Badamosi Babaginda, the President (The Vanguard, 2008, p. 39). Abiodun Olaku painted series of works that are reflecting the conditions of Lagos slums in order to draw the attention of government to the sordid situations confronting the common man in the Nigerian society. (Seminar series, 2007, p. 16). Mufu Onifade's portrayal of societal beliefs and disbeliefs in Asoro Dayo and Ooyamayawa symbolizes the hospitality of Yoruba people to strangers. Joshua Nmesirionye's Symphony depicts a busy market scene in Lagos where people buy and sell. Francis Uduh's Resource Control is a manipulation of cold-cast technique to suggest government disproportionate sharing of resources with regards to the Niger-Delta region of Nigeria. (Website: www.universalstudiosofart.com). 


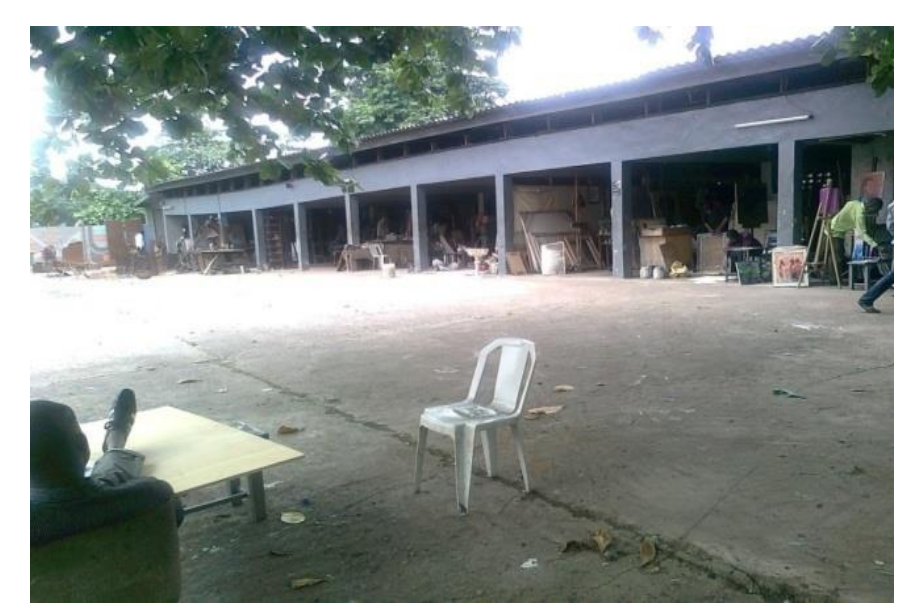

Plate 2: Section by Section. (C) Augustine Bardi

\section{Acquisition of conducive environment for art Practice}

The art of our living as humans must be sustained according to Torii. To maintain the earth's continual existence the environment must be secured to allow other creative mechanism to evolve successfully. In art, it takes a careful composition to assemble the elements of art, so it takes the art of environment to function with minimal abuses (Torii, 2015, pp. 314-315). After the struggle to resist ejection from the site allocated to the artists of Universal Studios of Art, they were moved to a place that was not conducive to creative activities. The artists endeavoured to clean up the environment, as earlier discussed, and the new studio was opened with an inaugural exhibition titled Stride in Time. Members were allocated to various studios (Plate 2). The photograph in Plate 3 depicts an environment that is good for effective knowledge dissemination in the field of art.

This environmental issue was brought to an end under the leadership of the older artists who were operating the studio and this encouraged the students on industrial attachment as well as those on apprenticeship programmes who were busy learning (Plate 3). In keeping with the law of cleanliness, with the present regime in power in Lagos state, a visit recently to the studios showed remarkable improvement with regards to sanitation. With this, it is hoped that if the promises of the Lagos State government with regards to clean environment is sustained, the studios will totally meet all required standards.

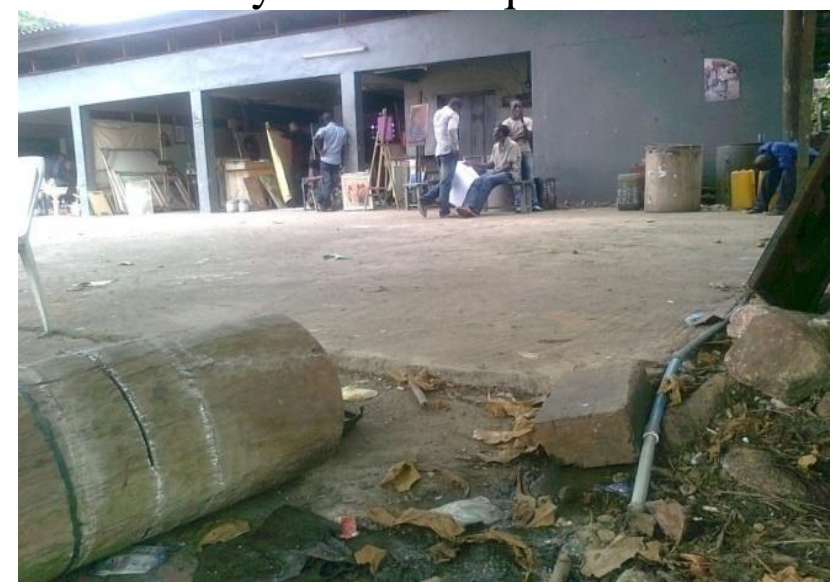

Plate 3: An environment for effective learning. Universal Studios of Art. ( $)$ Augustine Bardi 


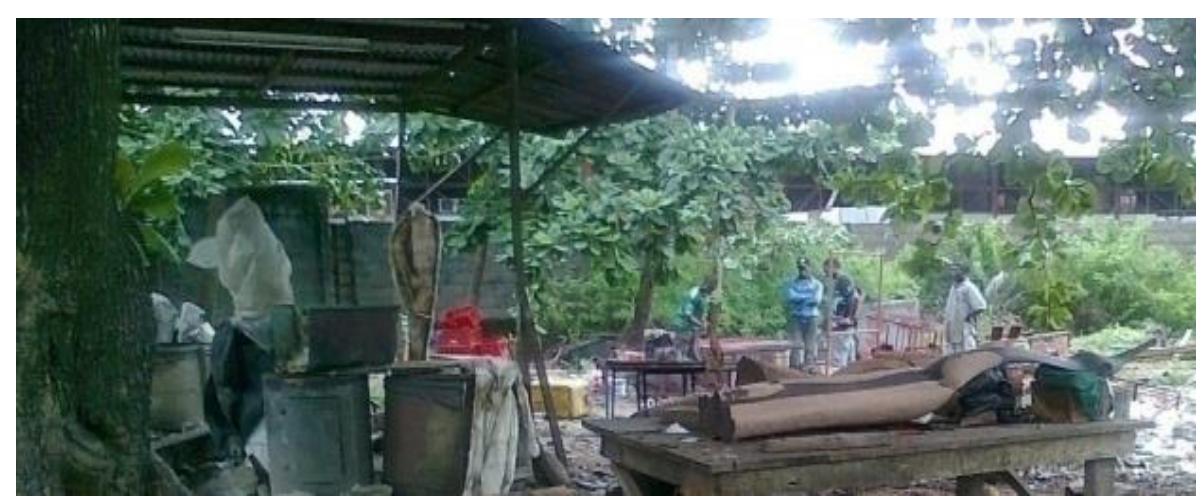

Plate 4: Students on Industrial Training. Universal Studios of Art.@ Augustine Bardi

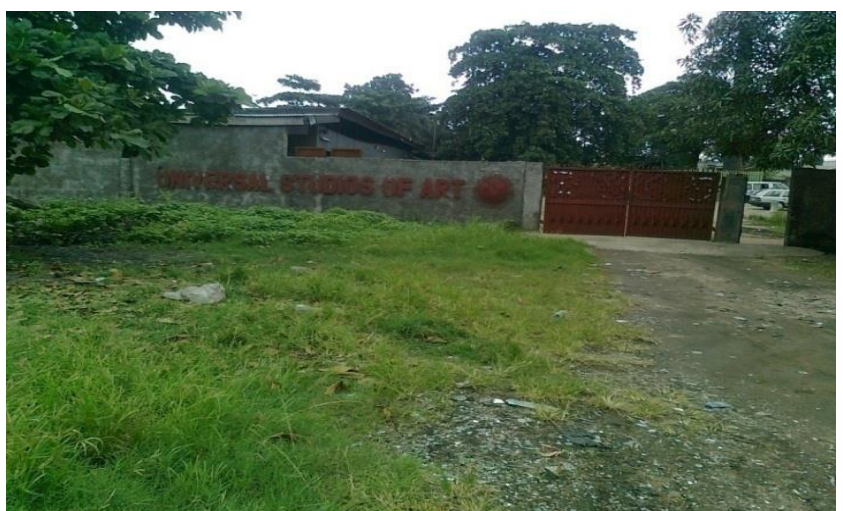

Plate 5: Entrance, Universal Studios of Art.(C) Augustine Bardi

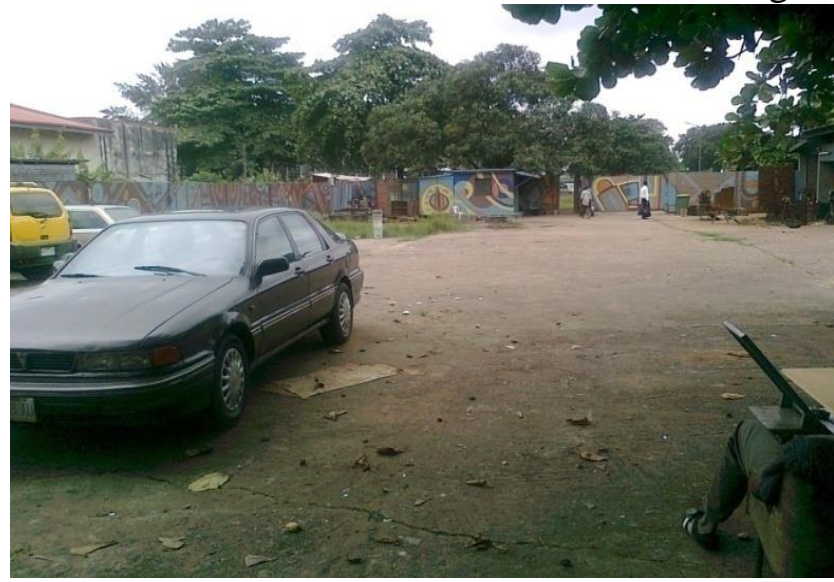

Plate 6: Exit, Universal Studio of Art. (C) Augustine Bardi

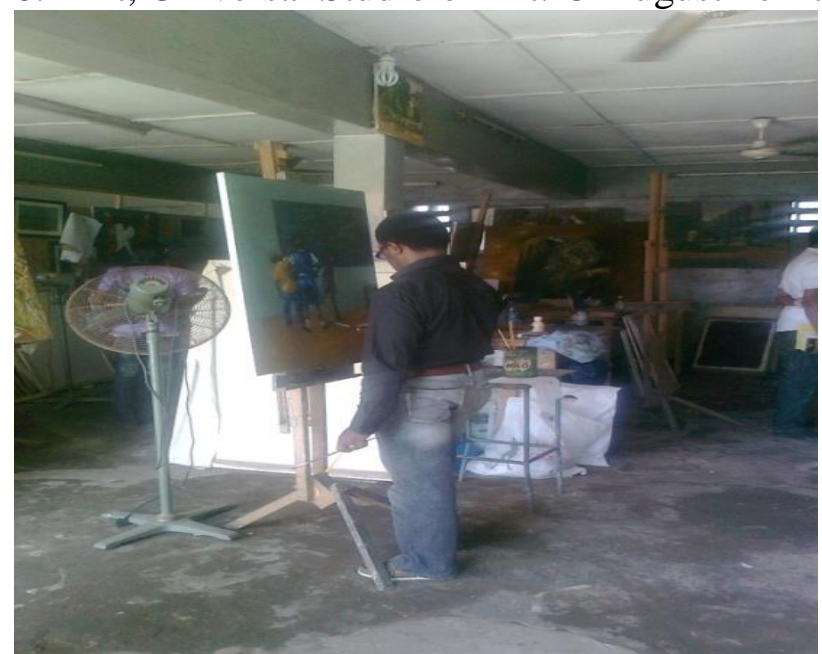

Plate 7: Emeka a Banker-Artist. (C) Augustine Bardi 


\section{Training of Nigerian Youth}

One of the primary objectives of the Universal Studios of Art is to provide an enabling environment for cross fertilization of ideas, techniques and styles and to train young Nigerians as artists (Plate 7). The organizers of the Universal Studios of Art encourage participation from students on industrial training (I.T) as well as run apprenticeship programme for pupils who have the knowledge of fine arts and still wish to continue to improve on their skills (The Guardian, 2008, p. 35). Also according to paper, the Students on industrial training spend a minimum of 3 months and a maximum of 6 months, depending on their level of improvement, while those running apprenticeship scheme stay between 4 to 6 years, depending on their level of proficiency".

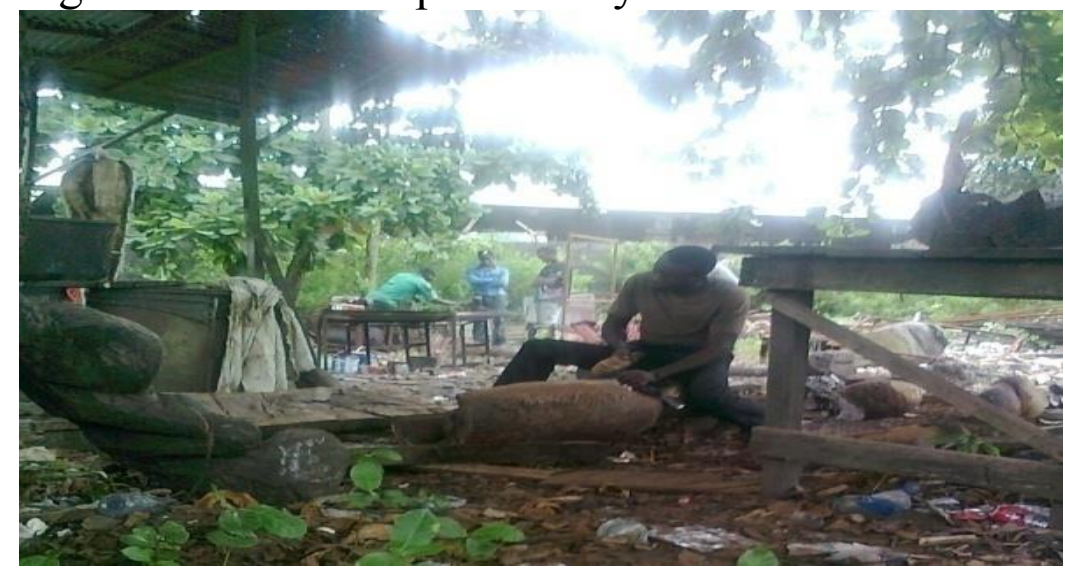

Plate 8: A youth chiseling, Universal Studios of Art. () Augustine Bardi

The young artists who join the studio as artists-in-residence are Polytechnic or University graduates who could stay for about 6 months. (An Interview). It is, however, interesting to know that over eighty to one hundred students participate in the programme yearly. The students are encouraged and supported by the organizers, the Universal Studios of Art. The training is free, and the studio management provides clay for students. The studio has never received internal or external grant or support, but, co-operate bodies like Total petroleum, Nestle Foods and others assist, while patrons of galleries supply art materials. However, the USA pays to the National Gallery of Art (N.G.A) authorities about N500, 000.00 as rent (An Interview). The contributions of the Universal Studios of Art Artists remain inexhausive. The qualities of subjects taught in the studio are the same with those that are taught in other formal art schools in Nigeria and elsewhere in the world. The activities of the studio started sixteen years ago, while the residency programme for independent artists at the National Studios under the Gallery of Modern Art started thirty one years ago. It should be noted that the standard of the former is by far higher than the latter. A countless number of young artists have benefitted from the studios for over two decades.

\section{Conclusions}

Many discussions have been advanced in this study. For example, in Europe, vocational trade schools were introduced to benefit the society. Art was among the trade introduced because of its aesthetic and creative qualities. The 
coming of Art training and artistic profession stimulated movements like the Renaissance, Cubism, Impressionism and others. The vibrancy of these movements led to the establishment of studios, schools and workshops for apprenticeship that trained the formal and the informal artists in Europe.

It has been revealed that the European experience has been transferred to Africa, and particularly to Nigeria, where informal training has existed through studios and workshops. For example, some Artists have been trained in different workshops across Nigeria. Notable among these were the Kevin Carroll's Oye Ekiti experiments, the Mbari-Mbayo workshop in Oshogbo, Ori-Olokun in IleIfe, the Abayomi Barber School in Lagos, the Harmattan workshop at AgbrhaOtor and the Universal Studios of Art in Lagos, which is the focus of this study. There are also the guild of bronze casters and carvers operating at Igun Street and Igbesanwan in Benin City. The characteristic nature of all these aforementioned workshop centers is knowledge dissemination through informal art training. The establishment of the National Theatre that hosted the (Festac)' 77 in Lagos has advanced the development of workshop practice in Nigeria. The National Theatre's management invited some independent artists like Bisi Fakeye, Amos Odion, Erhabor Emopkae, Joe Musa and Monday Akhidue to train the young ones and art enthusiasts. It was sad to note that as more participants joined the workshop practice the independent artists were served quit notice to leave the National Theatre premises by this same management though in national interest, as it later proved to be.

However, the leadership role that has been played by the artists of the Universal Studios of Art and other Studios or workshop centers in Nigeria will forever be commended by prosperity. Despite the accolades and commendations from different quarters, myriads of pejorative connotations have also been used to demoralize artists and art in Nigeria. With the vibrant activities of most art centers in the country, it is obvious that art, as a profession, has come to stay in contemporary Nigerian society. It is a basic fact that the National Council for Arts and Culture (N.C.A.C.) has a focus and the National Gallery of Art (NGA) has a project to develop Nigerian art, but at their own pace. Bisi Fakeye and his team saw very much beyond this snail movement, and despite all odd circumstances, they forged ahead to create a conducive milieu in order to produce great works of art, and indeed they have.

The Universal Studios of Art remains a centre of artistic and creative excellence, going by its contributions to the development of unique art tradition in Nigeria. The establishment or up-grading of this Studio in 1995 by Bisi Fakeye and other notable artists has made it more seriously part of Nigeria's history. The resilience of the artists of the Universal Studios of Art after their forceful, but promising and eventful, ejection from their age-long location, remains unforgettable in the memories of the USA artists and their art admirers. It will be incomplete to celebrate the present creative, socio-cultural, educational and, generally, developmental successes of this informal art monument, now an international centre, in Nigeria without remembering the following: Dr. Chike Dike (former NGA Director-General and egoists misunderstood art visionary), 
Dr. Walter Ofonagoro (former Minister of Culture and Tourism), Bisi Fakeye (the unrepentant defender and embodiment of USA), the late chief Okpu Eze (former SNA President) and Professor Ola Oloidi (Professor of Art History and SNA executive member). Both Okpu Eze and Ola Oloidi were able, during the bitter relocation controversy; to effortlessly mobilize needed psychology, wisdom and spirituality to bring peace to the innocently warring sides. Of course, the roles of Abiodun Olaku, Bunmi Babatunde, Monday Akhidue and others should also be appreciated for giving their master, Bisi Fakeye, the needed cooperation. However, like the creative self-effort and perseverance of Ori-Olokun workshop, Mbari-Mbayo experience and Oye-Ekiti Experiments, the Universal Studios of Art has remained very good stimulative name in modern Nigerian visual arts. The Universal Studios of Art has developed greatly through self effort, and determination, and its history has become that of creative growth, cultural ideology, dynamic nationalism, art internationalization, progressive radicalism or Protestantism and artistic pride.

\section{Bibliography}

1. Abaje, K. (2008). The National Gallery of Art, An Unpublished B.A. Project, Department of Fine and Applied Arts, Benin: University of Benin.

2. Gauvard, C. (1999). Il etait une fois la France, Vingt siecle d'Histoire. Publie par Selection du Reader's Digest Paris. pp. 116-121.

3. Oloidi, O. (2011). The Rejected Stone: Visual Arts in an Artistically Uniformed Nigerian Society. Nsukka: University Nigeria Nsukka Ceremonial Committee.

4. Hutyrova, M. (2016). Utilization of Narrative Approach in Art Therapy in Children with Behavourial Problem. Review of Artistic Education, 11/12, 284285.

5. Bankole, O. (2004). The Missing Link in Academic Training and Professionalism in Art and Design in Nigeria. Creative Dialogue: Journal of the Society of Nigerian Artists, 2, 15.

6. Wangboje, S. (1998). Wangboje: Thirty Years on the Road: A Retrospective. Sponsored by Mobil Oil. (Exhibition Catalogue), p. 9.

7. Stride in Time. An Exhibition Catalogue of Paintings, Ceramics, Textiles, Graphics and Sculptures by the Universal Studios of Art, Lagos, 12-25, April, (Lagos: Russian Cultural Centre, 1996), pp. 1-2.

8. Rejuvenation: An Exhibition Catalogue of Contemporary Nigerian Art by Society of Nigerian Artists (S.N.A), Lagos, 24 June-8 July, (Lagos: Universal Press, 2005), pp. 11-12.

9. Resurgence: An Exhibition Catalogue of Paintings, Sculptures and Drawings by the Universal Studios of Art, Lagos, 8-18, April, (Lagos: Terra Kulture, 2006), pp. 7-28.

10. In Due Season. An Exhibition Catalogue of Paintings, Sculptures and

Drawings by the Universal Studios of Art, Lagos, 5-22, December, (Lagos: Mydrim Gallery, 2007), p.18. 
11. Oloidi, O. (1999). Art and Nationalism in Colonial Nigeria. Nsukka Journal of History, 2(1), 96.

12. Vasiliu,, L.O. (2016). Distinctive features of Music Education in Lasi: An overview after 155 years. Review of Artistic Education, 11/12, 115.

13. Resurgence: An Exhibition Catalogue of Paintings, Sculptures and Drawings by the Universal Studios of Art, Lagos, 8-18, April, (Lagos: Terra Kulture, 2006), p. 13.

14. Poliakova, N. \& Kralova, E. (2015). Potency of Music and Movement stimulation in the Health care of Patients with Parkinson Disease. Review of Artistic Education,11/12, 164.

15. 4th USA Annual Seminar Series. The Challenges of Art Practice in a Developing Economy by the Universal Studios of Art. 5-22, 2007. p. 16.

16. The Universal Studios of Art. (www.universalstudiosofart.com)

17. Torii, C.V. (2015). The Art of Environmental awareness training in the Secondary teaching system. Review of Artistic Education,11-12, 314-315.

18. An interview with Bisi Fakeye (Sculptor) Universal Studios of Art, Lagos, September, 2011.

19. An interview with Patrick Agose (Sculptor), Universal Studios of Art, Lagos, September, 2010.

20. The Guardian, Tuesday, September 19, 2007, "ARESUVA.....Birth of Continental Platform for Visual Art". p. 35.

21. The Guardian, Tuesday, December 18, 2007. Harvest in Due Season with "USA" Artists, p.85.

22. Bunmi Babatunde (Sculptor). (2008, September). An interview - Universal Studios of Art, Lagos.

23. The Guardian, Tuesday, October 7, 2008. When Nigerian Artists Stormed Las Vegas Art Expo, p. 105.

24. The Guardian, Tuesday, October 7, 2008. When Nigerian Artists Stormed Las Vegas Art Expo, p. 107.

25. Cancer with colors of Hope. (Tuesday October 28, 2008). The Guardian, p. 118.

26. Vanguard, Tuesday, January 15, 2009. “2008: NGA's Year of Visual Art Glory", p. 38.

27. Vanguard, Tuesday, January 15, 2009. “2008: NGA’s Year of Visual Art Glory”, p. 39.

28. Daily Sun, Wednesday, October 17, 2009. Female Artists Celebrate Womanhood in Lagos, p. 28. 